derly. Prevalence of Parkinson's disease and related disorders assessed by a door-to-door survey of inhabitants older than 65 years. Arch Neurol 1995;52:1017-1022.

12. Morgante L, Rocca WA, Di Rosa AE, et al. Prevalence of Parkinson's disease and other types of parkinsonism: a doorto-door survey in three Sicilian municipalities. The Sicilian Neuro-Epidemiologic Study (SNES) Group. Neurology 1992; 42:1901-1907.

13. Bharucha NE, Bharucha EP, Bharucha AE, Bhise AV, Schoenberg BS. Prevalence of Parkinson's disease in the Parsi community of Bombay, India. Arch Neurol 1988;45:13211323.

14. Wang SJ, Fuh JL, Teng EL, et al. A door-to-door survey of Parkinson's disease in a Chinese population in Kinmen. Arch Neurol 1996;53:66-71.

15. Li SC, Schoenberg BS, Wang CC, et al. A prevalence survey of Parkinson's disease and other movement disorders in the People's Republic of China. Arch Neurol 1985;42:655-657.

16. Menniti-Ippolito F, Spila-Alegiani S, Vanacore N, et al. Estimate of parkinsonism prevalence through drug prescription histories in the Province of Rome, Italy. Acta Neurol Scand 1995;92:49-54.

17. Mayeux R, Denaro J, Hemenegildo N, at al. A populationbased investigation of Parkinson's disease with and without dementia. Relationship to age and gender. Arch Neurol 1992; 49:492-497.

18. D'Allessandro R, Gamberini G, Granieri E, Benassi G, Naccarato S, Manzaroli D. Prevalence of Parkinson's disease in the Republic of San Marino. Neurology 1987;37:1679-1682.

19. Wermuth L, Joensen P, Bunger N, Jeune B. High prevalence of Parkinson's disease in the Faroe Islands. Neurology 1997; 49:426-432.
20. Bennett DA, Beckett LA, Murray AM, et al. Prevalence of parkinsonian signs and associated mortality in a community population of older people. N Engl J Med 1996;334: $71-76$.

21. Tandberg E, Larsen JP, Nessler EG, Riise T, Aarli JA. The epidemiology of Parkinson's disease in the county of Rogaland, Norway. Mov Disord 1995;10:541-549.

22. Baldereschi M, Di Carlo A, Rocca WA, et al. Parkinson's disease and parkinsonism in a longitudinal study: two-fold higher incidence in men. ILSA Working Group Italian Longitudinal Study on Aging. Neurology 2000;55:1358-1363.

23. Ben-Shlomo Y, Marmot MG. Survival and cause of death in a cohort of patients with parkinsonism: possible clues to aetiology. J Neurol Neurosurg Psychiatry 1995;58:293-299.

24. Miller DB, Ali SF, O'Callaghan JP, Laws SC. The impact of gender and estrogen on striatal dopaminergic neurotoxicity. Ann NY Acad Sci 1998;844:153-165.

25. Martilla RJ, Rinne UK. Epidemiology of Parkinson's disease in Finland. Acta Neurol Scand 1976;53:81-102.

26. Rosati G, Granieri E, Pinna L, et al. The risk of Parkinson's disease in Mediterranean people. Neurology 1980;30:250255.

27. Okada K, Kobayashi S, Tsunematsu T. Prevalence of Parkinson's disease in Izumo City, Japan. Gerontology 1990;36:340344 .

28. Bower JH, Maraganore DM, McDonnell SK, Rocca WA. Incidence and distribution of parkinsonism in Olmsted County, Minnesota, 1976-1990. Neurology 1999;52:1214-1220.

29. de Rijk MC, Breteler MM, Graveland GA, et al. Prevalence of Parkinson's disease in the elderly: the Rotterdam Study. Neurology 1995;45:2143-2146.

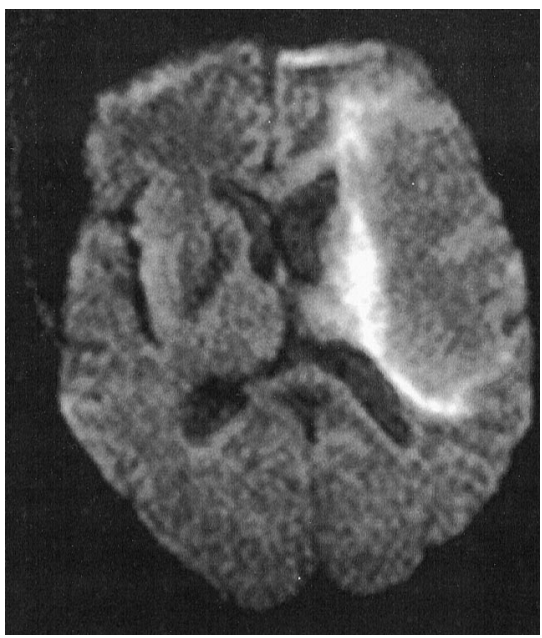

Figure. Diffusion weighted imaging (echoplanar, repetition time $=5100$ milliseconds, echo time $=137$ milliseconds, $b=1000 \mathrm{~T}$ ) showing a rim of high signal surrounding a lesion that does not demonstrate signal change or mass effect.

\section{Progressive multifocal leukoencephalopathy}

R.D. Henderson, FRACP, M.G. Smith, MBBS, P. Mowat, FRACR, and S.J. Read, MBBS, PhD, FRACP, Brisbane, Australia

A 58-year-old woman admitted to the hospital had a 3-month history of progressive neurologic deterioration

\section{Neuro Images}

characterized by severe global aphasia and bilateral limb weakness, greater on the right. The patient had a 10-year history of systemic lupus erythematosus (SLE). Polyarthritis had been present for 6 weeks before the onset of neurologic symptoms; she was treated with prednisone and methotrexate. A diagnosis of progressive multifocal leukoencephalopathy (PML) was established by a positive PCR for JC virus from CSF. The patient deteriorated and further active care was withdrawn.

Serial MRI showed an enlarging area of hypointensity on T1 and hyperintensity on T2-weighted images in the left parietal lobe. The lesion involved predominantly white matter and was without mass effect. A rim of high signal was present at the margins of the left parietal lesion on the diffusion-weighted image (figure) with a reduced apparent diffusion coefficient $(\mathrm{ADC})$ on the $\mathrm{ADC}$ map. There was no enhancement after administration of IV gadolinium.

PML in SLE treated with immunosuppression is uncommon. ${ }^{1}$ The MRI findings in PML often include circumscribed lesions predominantly in white matter without mass effect or contrast enhancement. ${ }^{1,2}$ The MR sequences indicate a progressing area of cytotoxic edema surrounding prior areas of white matter damage. ${ }^{2}$

1. Ahmed F, Aziz T, Kaufman LD. Progressive multifocal leukoencephalopathy in a patient with systemic lupus erythematosus. J Rheumatol 1999; 26:1609-1612.

2. Ohta K, Obara K, Sakauchi M, Obara K, Takane H, Yogo Y. Lesion identification by diffusion-weighted magnetic resonance imaging in progressive multifocal leukoencephalopathy. J Neurol 2001;248:809811. 


\section{Neurology}

\section{Progressive multifocal leukoencephalopathy}

R. D. Henderson, M. G. Smith, P. Mowat, et al.

Neurology 2002;58;1825

DOI 10.1212/WNL.58.12.1825

This information is current as of June 25, 2002

\section{Updated Information \& Services}

\section{References}

Permissions \& Licensing

Reprints including high resolution figures, can be found at: http://n.neurology.org/content/58/12/1825.full

This article cites 2 articles, 0 of which you can access for free at: http://n.neurology.org/content/58/12/1825.full\#ref-list-1

Information about reproducing this article in parts (figures,tables) or in its entirety can be found online at:

http://www.neurology.org/about/about_the_journal\#permissions

Information about ordering reprints can be found online:

http://n.neurology.org/subscribers/advertise

Neurology ${ }^{\circledR}$ is the official journal of the American Academy of Neurology. Published continuously since 1951, it is now a weekly with 48 issues per year. Copyright . All rights reserved. Print ISSN: 0028-3878.

Online ISSN: 1526-632X.

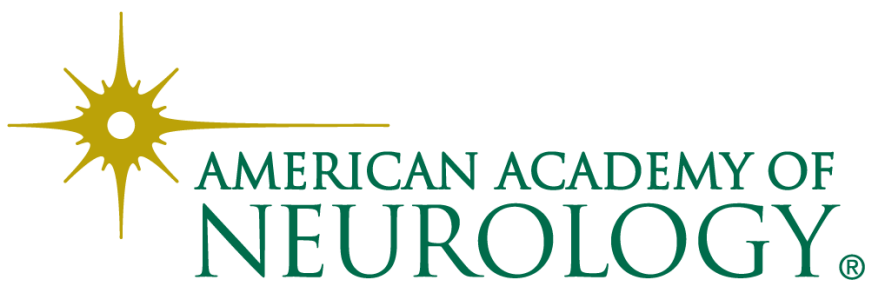

